\title{
Study on Management Based on eHR of Key Employees in Chinese Iron and Steel Enterprises:A Case of W Group Corporation in China
}

\author{
Liu $\mathrm{Hu}^{*}$ \\ Institute 0f Management \\ Hubei Business College \\ Wuhan, China \\ 787650301@qq.com
}

\author{
Yanjun Li \\ Wuhan Iron and Steel Group Coporation \\ Wuhan, China
}

\begin{abstract}
As the faster and faster integrating of world economics integrating, China adjusting her steel and iron industrial policy, and more and more cross-area industrialchain-extending steel enterprise group merges through reorganizing and technology updating, enterprises compete has in human resources instead of fund. Person with ability, especially the key employees who becomes the fountainhead of enterprise core competitive ability, now inevitably becomes the focus of world competition. Under the strategy human resources management background, this research, take W Group Corporation in china for an example, discusses the environment of the key employees information management by introducing the thought of system project, and explores the key employees information management the method by modern computer and network technology.
\end{abstract}

Keywords-Key employee; Information management; Iron and steel enterprises

\section{INTRODUCTION}

With China's sustained and rapid economic development, China has become the world's largest steel consuming countries and the largest steel producer in the world. At the same time, the acceleration of the trend of economic globalization, at the same time bring a far-reaching impact on the global steel industry market order and industrial pattern of China's iron and steel industry caused a huge impact. China's steel enterprises have not had time to fully realize the shift from global export capacity to the "global business", like India Arcelor Mittal Group ranked first in the world, South Korea's POSCO, ThyssenKrupp multinational steel giant is known for its abundant capital, advanced technology and quality products strength in China quietly layout, trying to fierce competition in the Chinese domestic market and local enterprises in China.

With the development of the world's steel industry unprecedented opportunities and challenges, China steel industry organizational restructuring, the implementation of the merger, reorganization, expand the size of the enterprise groups have a comparative advantage, improve industrial concentration. The number of iron and steel smelting enterprises was a substantial decrease in steel production of China's top ten steel enterprise groups accounted for the proportion of national output reached more than $50 \% ; 2020$ to reach more than $70 \%$ "," support and encourage qualified of large enterprise groups, cross-regional joint reorganization, , the formation of two 3000-ton, several tens of millions of tons of internationally competitive large enterprise groups "a major decision. In accordance with this policy, the domestic steel leading enterprises have accelerated the pace of expansion: Baosteel Group alliance with Maanshan Iron and Steel; Angang joint reorganization Benxi Iron and Steel; Shougang Group and Tangshan Bao Steel group formal cooperation....

Expansion of enterprise scale application of advanced technologies, are inseparable from the people, especially for enterprises engaged in value-added core staff, today the focus of competition between the iron and steel enterprises is the competition for talent[1]. In the economic globalization and multinational companies under the background of talent localization strategy implementation, enterprises will face more and more fierce talent competition. But with the development of knowledge economy, knowledge and technology are highlight in an enterprise, to master advanced technologies and management of knowledge staff is playing an increasingly important role in the enterprise, the value of core employees has become more and more obvious, the study of the core staff has received widespread attention. Which employees are the company's key employees, and how good the company's key employees management in a highly streamlined management conditions, became the senior management of China's iron and steel enterprises growing needs and desires.

The 21 st century is a new era of knowledge economy, human resources information management is core component of the information management[2]. From in academic and corporate research current situation of human resources information management, its research content are mainly concentrated on human resource information management function realization, in recent years, there are also some scholars to study the new mode of human resources information management from the height of the corporate strategy, including data mining and decision support technology, etc. this paper argue, human resources information management not only can find out more efficient, more scientific management methods from the perspective of the process, but also can explore innovative human resource information management from the point of human resource management, in order to inspire our change management 
thinking from the enterprise development strategy need. Dynamic information management environment of key employees are discussed in this paper, including the improvement of human resources information platform, the construction specification, key indicators of evaluation system for employees of the $\mathrm{B} / \mathrm{S}$ architecture of the eHR system, improve the system of eHR management, effective employee training and so on. Based on the theory of practice[3], not only can realize the function of information management itself, but also to promote enterprise realize the strategic level of comprehensive human resource management also has the vital significance.

\section{THE CONNOTATION OF CORPORATE KEY EMPLOYEES}

The importance of human resources for the development of enterprises is becoming increasingly apparent, the competition among enterprises have been transformed for the competition for key employees. However, from this stage theory and business circles of the key employees of view, in its connotation defined and the method for determining is far from reach agreement on in-depth analysis of key employees and enterprise development, improving the management of the enterprise's key employees as well as to enhance the core competitiveness of enterprises have a great impact. Therefore, it is necessary to in-depth study for the status quo of China's enterprises key employees connotation, clearly define and determine the method of key employees. Combing through the many references, this paper summarizes the meaning defined in the following categories more representative of their core employees:

First, key employees are the most important and the most difficult to find, indispensable, and the most difficult to replace, to ensure the company a key figure in the success of the strategy.

Second, key employees in the enterprise, and a long-time education and training in the workplace, higher professional and technical skills, our industry a wealth of experience and outstanding technology development or business management in order, they are the scarcity of human resources is the fundamental source of the core competitiveness of enterprises.

Third, the key employees refers to such employees, their jobs require a long-time education and training, must have high technical expertise and skills, such as the Chief Financial Officer and excellent technical developers; or our industry rich of experience and outstanding business management skills, such as sales manager and general manager of the enterprise, their numbers are small, but important, once the core of employee turnover, will adversely affect the normal production and operation of enterprises, and vacancy work The job is difficult to find the right person to replace. Even if it is found, the cost of recruitment and training costs will be high.

Fourth, the so-called key employees, are to master the core technology, engaged in the core business as well as employees in the core positions.

Fifth, key employees of the enterprise is the key skills of the workforce has constituted a source of core competitiveness of enterprises, with specialized technology, grasp the core business, control of critical resources, worked in important positions, with a strong business sense of loyalty and for business that part of the groups that have made outstanding contributions and growth can also be known as key employees or key employees.

Sixth, key employees who have high professional technology and skills in the enterprise or the industry has a wealth of experience and outstanding business management skills, employees can make a significant contribution for the enterprise[4]. Their substitutability smaller, replacement cost is higher, is the scarcity of resources, the development of enterprises play a central role.

Learn from the above point of view on the basis of the combination of the author's understanding of the key employees connotation in the study and work, the paper argues that in order to more accurately determine whether the employee for the company's core staff, and can be from the following aspects The connotation define:

Firstly, whether they have a unique core competencies, the company's key employees must first have a high degree of enterprise value, they have mastered certain people, financial, physical, information and other core resources and has a specialty such as professional technical skills, outstanding management skills, skilled financial management capacity or excellent marketing ability, and so on. Key employees are different from the specific requirements with the general staff and reflect general on the qualities and abilities, only to have these resources and capabilities it possible for businesses to make a greater contribution to the development of enterprises have a greater impact.

Secondly, the core competencies are consistent with the company's development strategy[5]. Under the premise of employees have certain core competencies or strengths, and only when consistent with this core competency and business development strategy, will bring to the enterprise-effective, but also to be able to be business as core staff. In different stages of enterprise development strategy, the company's key employees change.

Thirdly, key employees have a high scarcity degree of talent. In particular, scarcity of performance for key employees not only has its own expertise in technology, management, and more importantly, their technology, knowledge, customer relationships and resources is a relatively small number of similar talent in the labor market in the short term, instead of poor recruitment costs and reset training costs are much higher than the general staff.

Fourthly, key employee should be in the key positions[6]. Because only when the employees is in key positions on the value of its own in order to be able to give full play to create value for the enterprise, which is a prerequisite for the enterprise, otherwise these people is a waste, not to the enterprise development have a decisive effect.

Fifthly, whether he or she has a higher company loyalty. Key employees with high-performance and high-value, on the market in a dominant position, its corporate loyalty is not high, it is difficult to ensure that the enterprise technology and 
business secrets undamage, so key employees must be selected from those who agree with the concept of corporate culture in longer working hours, excellent staff.

\section{INFORMATION MANAGEMENT OF KEY EMPLOYEES}

\section{A. The Identification of the Key Employeesof the W Group Corporation}

Group $\mathrm{W}$ is a national investment in the construction of a super-sized iron and steel enterprises in nearly 50 years of construction and development process of China's national economy and modernization have made important contributions. Group W steel products mainly include hundreds of hot-rolled coil, hot rolled steel, hot-rolled heavy rail, plate, cold rolled coil, galvanized sheet, tin plate, silicon steel, painted steel, high-speed wire varieties.

Group $\mathrm{W}$ have 17 organs and departments, a direct wholly-owned subsidiary of 32, 19 holding companies, Branch 7. At present, the company had a total of 7.3 million workers in the post.

In accordance with the principle of consistency with the strategic direction, we first determine the key employees of the Group W jobs for steel products R \& D, production, sales and functions of management units and departments. These include:

Group Headquarters: Office of the party and government, the Department of Production Technology, Planning and Development Department, Human Resources Department, Finance Department.

$\mathrm{R}$ \& D units: Institute of Science and Technology Industrial Park.

Production units: Steel AG, mining, energy and power companies, transportation companies, Ports Corporation, equipment maintenance company.

\section{Sales: Sales Company, Customer Center.}

And then have a certain core competencies principle, within the scope of the unit in accordance with the management, technology and operation of three kinds divided. The basic criteria: (1) management: the leadership of the group of companies, the headquarters functions departmental managers, the two units principal leaders; (2) technical staff: production, $\mathrm{R} \& \mathrm{D}$ units directly engaged in research or production with senior technical titles or master's degree or more qualifications of staff; (3) Operator: production units directly engaged in the production of professional qualification or have a technician personnel for the title of corporate-level technical experts.

Finally, the company and each unit of human resources management department personnel initially included in the company's key employees range stratified responsible way to conduct a comprehensive inspection, and ultimately determine the company's key employees candidates.

According to the statistical results of the W Group Human Resources Department of the Company, the final 618 managers, 2,076 technicians and 1,311 operators included in the scope of the company's key employees management, accounting for $5.49 \%$ of the total employees of the Group, $11.44 \%$ of the total employees 35,000 .

\section{B. W Group's Key Employeesinformation Management Model}

in recent years, human resource management in the iron and steel industry rapid development of information technology. World Steel renowned companies such as U.S. Steel Union, Australia and Steel Union, Thyssen Krupp and other world-class iron and steel enterprises, human resource management information technology has experienced decentralized management to group management and control of the development process, and high-performance culture , and gradually formed a high-performance human resource management and control model. Domestic iron and steel enterprises in the information technology began in the 80 s of last century, the true sense of the enterprise information in this century has just started. Over the past few years, the iron and steel enterprise information in terms of scale, efficiency, technology continues to progress, a total investment of about 50 billion into more than 50 enterprises of the China Iron and Steel Association statistics object has 17 basic information technology, is the construction of information, 10, 10, project and prepare project of China's iron and steel enterprises in information technology is a breakthrough in.

However, our survey found that China's iron and steel enterprises have not a company uses information technology to the key employees dedicated management. To this end, we propose the management of the "core" of the key employees in the human resources information system based on the use of advanced information technology.

\section{W Group's Key Employeesinformation Management System Implementation}

System environment: from the trend of the development of computer technology, computer network is bound to become an important means of enterprise competitiveness, according to the current state of technology, we use the B / S three-tier architecture + Microsoft NET development platform + SQL Server database environment portfolio.

System module: as shown in the previous system model, the system is a very open platform, users can redefine the input and output of the system based on the actual development of the company, to ensure that the system is capable of changing environment can play a role. Of course, the openness of the system is the user of the system is the prerequisite for the in-depth study of key employees management technology. At present, the system has been designed modules: core basic information about employees; key employees performance information; evaluation model of the core management staff; core technical staff evaluation model; core operations staff evaluation model; key employees level updates; system maintenance.

Database design: the system has access to the data used in all stored procedures to achieve the benefits of multiple SQL statements can be packaged together as a group to perform, thereby improving the access speed of the application. The 
specific design of the data sheet: basic information table Information, the major award table Encouragement, honor table Honor, the main thesis statement Paper, Academic table pluralism, comprehensive information evaluation table All-V management evaluation form Management- $\mathrm{V}$, technical staff the evaluation form Technology- $\mathrm{V}$ operating personnel evaluation table Skill-V, System Maintenance Table System.

\section{MANEGENMENT PeRformanCE ANALYSiS}

W group of companies has made significant performance in the key employees management after the enterprise use the eHR system, as the following survey results.

\section{A. The Satisfaction of Key Employees Have Much Improvement}

in a special study of manager construction in $\mathrm{W}$ group recently, 200 questionnaires were distributed and 197 effective recovery. That only do a better job in order to get a good evaluation results accounted for $83.4 \%$, respectively, compared with an increase of 36.7 percentage points and 23.8 percentage points in 2005 and 2006. It suggests a higher proportion of the tendency to agree with the results of performance appraisal, annual assessment that the result is excellent and competent to $30.8 \%$ and $68.7 \%$, respectively; very objective and the objective of $23.1 \%$ and $68.1 \%$, respectively.

\section{B. The Turnover Rate of Key Employeesnumber Has Been Reduced Significantly}

TABLE I. EMPLOYEES TURNOVER STATISTICS

\begin{tabular}{|l|c|c|c|}
\hline \multirow{2}{*}{ year } & \multicolumn{3}{|c|}{ The key employees turnover } \\
\cline { 2 - 4 } & $\begin{array}{c}\text { the total number of key } \\
\text { employees turnover }\end{array}$ & graduate & $\begin{array}{c}\text { undergrad } \\
\text { uate }\end{array}$ \\
\hline 2006 & 338 & 26 & 241 \\
\hline 2007 & 317 & 19 & 198 \\
\hline 2008 & 316 & 15 & 190 \\
\hline 2009 & 193 & 14 & 110 \\
\hline
\end{tabular}

From the above table (Table 1) it can be seen, since the use of the system, the total number of key employees turnover in W Group has been reduced significantly.

\section{The Capability of Independent Innovation Enhanced Significantly}

Since W Group Corporation implements eHR of Key Employees, 19 major science and technology of the W Group Corporation full implementation, 319 scientific and technological progress projects $100 \%$ implementation, the $70 \%$ of the project achieve substantive results. In addition, this year's awards to participate in the national, provincial and metallurgical industries, scientific and technological achievements of the Company to obtain the best results over the years, reporting a total of 73 , the grand prize of 1 , the first and second prizes also surpassed the previous years. At the same time, the company's patent applications this year, a record high in 2009, the company's patent applications for 105, three times in 2008; January to September 2010 reached a total of 202,that is the six times for the full year 2008 .

In brief, this research holds that the key employees information management is an item of systems engineering, it contains the key employees' recognition, constructing of appraisal target system, achieving of information technology as well as necessary training, drive, development etc. it's a series of work. Moreover, the applying of this model in W Group Corporation make it distinguishes the key employees from the dependence experience and intuition to the quantification recognition, from perception to rational. Finally, by studying the practice effect in $\mathrm{W}$ Group Corporation, this research also proves it's helpful to promoting group headquarters decision-making, the service function and the management of key employees.

\section{REFERENCES}

[1] W.G. Yang, "The key employeesand the enterprise's core competitiveness," Coal Economic Research, vol. 2001 (11), pp. 25-26.

[2] M.E. Kitces, "Partnership problem: Is the promise of a partnership the only way to Adequately reward key employees," Financia1 Planning, NewYork: Apr 1. 2006.

[3] H.J. Jiang, eHR. NET-based human resource management system design, 2005.

[4] Dess and D.S. Jason, "Vulunlary Turnover, Social Capital and Organizational Performance," Academy of Management Review, vol. 2001(26), pp. 446-456.

[5] H.W. Lee, "Developing new proficiencies for human Dianna L. Stone, Eugene F,Stone-Romero, Kimberly Lukaszewski, Factors affecting the acceptance and effectiveness of electronic human resource systems," Human Resource Management Review, vol. 2006(16), pp. 229-244.

[6] E. Donna, "Elementary Career Intervention Programs: Social Action Initiatives," Journal of Career Development, vol. 31(3), pp. 185-194, 2005. 